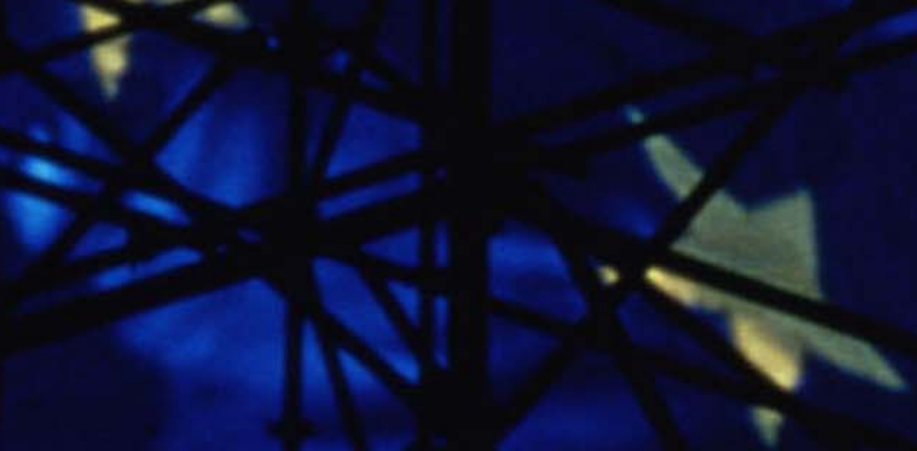

\title{
European Unions after the Crisis
}

\section{Roland Erne}

DEworking Paper1-
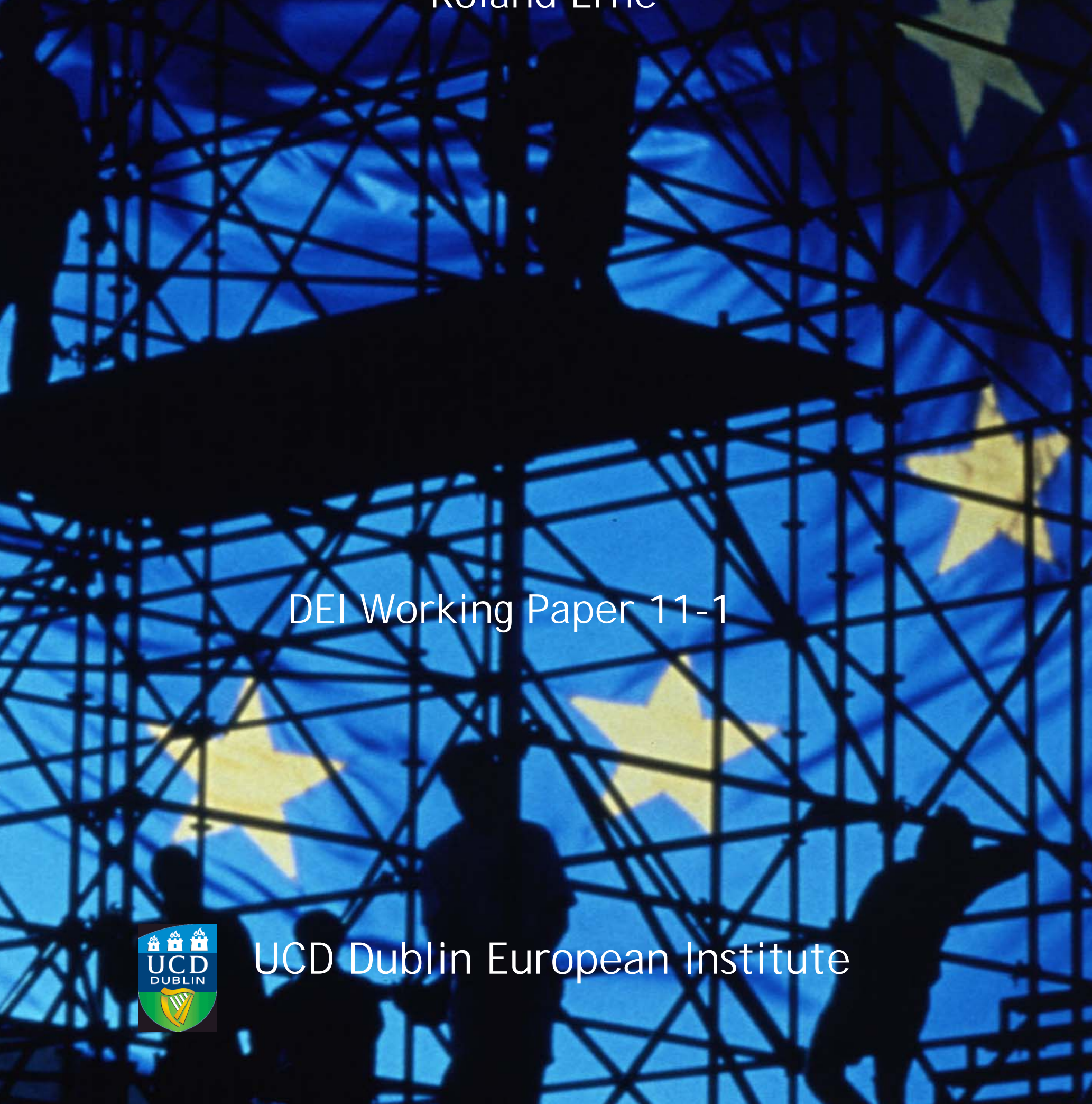
Working Paper: @ Roland Erne 2011

This paper should be cited as follows: Roland Erne, European Unions after the Crisis, UCD Dublin European Institute Working Paper 11-1, May 2011.

All opinions expressed are the sole responsibility of the author.

Cover Photo: @ European Union

\section{About the Author}

Roland Erne is a lecturer in industrial relations and human resources at University College Dublin's Quinn School of Business, and visiting fellow and adjunct professor at the Department of International and Comparative Labor at Cornell University's School of Industrial and Labor Relations. Contact: Roland.Erne@ucd.ie

\section{About the Dublin European Institute}

The Dublin European Institute (DEI) supports scholarly research and debate on the sources, processes and implications of European integration and governance. Based within the School of Politics and International Relations at University College Dublin, the DEI is the oldest and largest university centre for research on European affairs in the Republic of Ireland.

For more information, see: http:/ / www.ucd.ie/ dei or contact: Dublin European Institute, UCD School of Politics and International Relations, University College Dublin, Belfield, Dublin 4, IRELAND 


\title{
European Unions after the Crisis
}

\author{
Roland Erne \\ (University College Dublin)
}

\begin{abstract}
The economic and financial crisis has discredited the idea of a self-regulating market. Yet, it remains to be seen what measures society will be taking to protect itself against future fallouts of global markets. There is a growing consensus that the economy needs to be governed by tighter regulations. But this does not necessarily mean that the economy will be subordinated to democratic politics. Nevertheless, the paper concludes that any fatalism about the prospects of a democratic counter-movement against the marketisation of society is misplaced. Without doubt, the first reactions to the crisis namely the huge bailouts for private banks and the subsequent cutbacks in public services - do not augur well for the future of labour and egalitarian democracy. Conversely, the more socio-economic decisions are taken by tangible political and corporate elites rather than abstract market forces, the more difficult it is to mystify underlying business interests. The more visible business interests become, however, the easier it will be for social movements and trade unions to mobilise discontent and to politicise the economy.
\end{abstract}

\section{Keywords}

great recession; global financial crisis; bank bailouts; counter-movements; Karl Polanyi; Michael Burawoy; Colin Crouch; neo-liberalism, privatised Keynesianism; postdemocracy; European Union; trade unions; social movements; regulatory agencies; technocracy; countervailing interests, transnational collective action.

\section{Acknowledgements}

This paper will be published in the Festschrift for Colin Crouch, L. Burroni, M. Keune and G. Meardi (eds.) Economy and Society in Europe: A Relationship in Crisis, Cheltenham: Edward Elgar. An earlier version of the paper has been published in Italian: R. Erne (2011). "I sindacati europei dopo la crisi globale" In: Quaderni Rassegna Sindacale - Lavori XII (1) 157-76. I thank Hanspeter Kriesi, Guglielmo Meardi, Niamh Hardiman, and Sabina Stan for their helpful comments on earlier drafts of this paper. 


\section{Introduction}

The Great Recession of 2008-2010 has brought so much hardship to so many people across the globe that nobody can be happy about its occurrence. Even so, the current crisis of global financial capitalism is also enlightening, as it reveals concealed socioeconomic and political dynamics. The crisis not only causes pain, but also questions the legitimacy of free market capitalism and the dominant socio-economic and political order. Following Karl Polanyi’s ([1944] 2001) study of past waves of untempered global market capitalism, we should expect a rise of protective counter-movements that aim to subordinate the economy to society.

In its first section, this paper shows that the idea of a self-regulating market has once again been discredited. Yet, it remains to be seen what measures society will be taking to protect itself against future fallouts of the global markets. Whereas there is a growing consensus that the economy needs to be governed by tighter regulations, this does not necessarily mean that people around the globe will engage 'in a common effort to subordinate the economy to democratic politics and rebuild the economy on the basis of international cooperation' (Block 2001: xxxvii). Nevertheless, the paper concludes that any fatalism about the prospects of a democratic counter-movement against the marketisation of society is misplaced. Without doubt, the initial political reaction to the crisis - namely the huge bailouts for private banks and the subsequent cutbacks in public services - do not augur well for the future of labour and egalitarian democracy. Conversely, the more socio-economic decisions are taken by tangible political and corporate elites rather than abstract market forces, the more difficult it is to mystify the underlying business interests. Arguably, this also makes it easier for social movements 
to mobilise discontent and to politicise the economy.

\section{Rethinking economy and society after the crisis}

Days after the collapse of the global finance corporation Lehman Brothers a Guardian journalist asked a panel of experts and public intellectuals if the past week of turmoil has changed the world (Butselaar 2008). The heterodox US economist Joseph Stiglitz responded with the confidence of someone who is at long last winning the academic argument against his orthodox peers.

In some ways, from an intellectual perspective, this is as important as the Great Depression. The Depression taught us that markets are not self-correcting, at least not in the relevant time frame. This is a failure of microeconomics equivalent to the macroeconomic failures of the 1930s. The financial markets have not done what they are supposed to do, which is to manage risk and allocate capital well. The result is that there are no free-marketers left. Both the left and the right are arguing that there is a role for government to maintain the economy on an even level (Stiglitz 2008).

By contrast, the Canadian author and global justice activist Naomi Klein very much doubted that the global financial meltdown as such will lead to fundamental policy shifts away from the corporate pro-business paradigms that dominated economic policymaking since the late 1970s.

Nobody should believe the overblown claims that "free market" ideology is now dead. During boom times it is profitable to preach laissez-faire, because an absentee government allows speculative bubbles to inflate. When those bubbles burst, the ideology becomes a hindrance, and it goes dormant while the 
government rides to the rescue. But rest assured: the ideology will come roaring back when the bailouts are done. The massive debt the public is accumulating to bail out the speculators will then become part of a global budget crisis that will be the rationalisation for deep cuts to social programmes, and for a renewed push to privatise what is left of the public sector (Klein 2008).

Two years after the collapse of Lehman Brothers, Klein's doubts are proven to have been more than appropriate. The intellectual victories of heterodox economists over free-marketers in September 2008 did not prevent 'the great American robbery' (Stiglitz 2010a: 109) and the other bank bailouts that followed suit across the world. Moreover, the critical advice that the subsequent austerity measures will prolong the crisis and therefore cause unnecessary sufferings has been ignored (Krugman 2010).

Paradoxically, the financial meltdown showed that even the imminent ruin of a financial corporation can become an effective political tool for business interests. Obviously, corporations have an advantage not only because they tend to spend more money on political lobbying than other organisations. In capitalist democracies politicians structurally depend on the holders of capital, as shown by Claus Offe and Helmut Wiesenthal (1985). As any single investment decision - or corporate bankruptcy, as we might add in the light of recent events - has an impact on the economic growth of a territory, politicians must consider the views of capitalists whether they are organised or not. This simplifies the task of business interest representation enormously. Business associations do not face the difficult collective action problems that trade unions and other citizens' organisations face. Whereas investment strikes by capital holders do not require collective action, the withdrawal of labour requires organisation and the 
willingness of workers to act together despite the availability of individual exit options (Erne 2011). In this context, governments are not only implementing further privatisations of public services and welfare cuts. Governments, central banks, and supranational organisations, like the European Commission, the Organization for Economic Cooperation and Development (OECD), and the International Monetary Fund, are even advocating outright wage cuts and working time extensions that go beyond both the current working day and retirement age. Although neo-liberal theory is discredited, the political project that aims 'to re-establish the conditions for capital accumulation and to restore the power of economic elites' (Harvey 2005: 19) is still with us.

It seems that governments across the world have degenerated into a mere 'service provider for financial capital' (Bode and Pink 2010). Almost everywhere, democratic procedures have been bent to allow bank bailouts. Even in Switzerland, which is frequently portrayed as the most direct democracy of the world, the 6 billion francs bailout of UBS was adopted by an emergency ordinance of the executive that shielded the deal from being a subject of parliamentary and popular scrutiny (Bundesrat 2008, Boos 2008). Although the parliament subsequently supported the executive's action implicitly, namely by not calling it to account, the adoption of the UBS emergency decree 'in order to counter existing or imminent threats of serious disruption to public order or internal or external security' (Article 185-3 Swiss Constitution) effectively twisted the constitutional right of 50000 citizens to request parliamentary acts and emergency legislation to be submitted to a vote of the people (Article 141 Swiss Constitution). Arguably, 'theories and concepts of public law change under the impact 
of political events' as Carl Schmitt ([1922] 1985: 16), the infamous German lawyer and apologist of the fascist Führerstaat had argued.

Almost everywhere, advocates of deregulation, failed regulators, or investment bankers - thus, the people that have been responsible for the mess in the first pace - were put in charge of repair. Unsurprisingly, the solutions adopted to remedy the mess are based on the same principles that caused it in the first place. Toxic assets were simply shifted from banks to the government, even if that does not make them less toxic. Whereas the social welfare state meant protecting individuals against the failures of the market, the current crisis gave rise to a new 'corporate' welfare regime in which the state assumes the role as bearer of risk of last resort. When private financial firms were at the brink of collapse, their financial risks of gigantic proportions were simply shifted to the public. Consequently, Stiglitz had to revise his, above-mentioned, optimistic views of 2008: 'the Hooverites - the advocates of the pre-Keynesian policies according to which downturns were met with austerity - are having their revenge. In many quarters, the Keynesians, having enjoyed their moment of glory just a year ago, seem to be in retreat' (Stiglitz 2010b).

Given the ensuing legacy of public debt that 'will compromise economic and social programmes for years to come', the bank bailouts of the Bush and Obama administrations will almost surely 'rank among the most costly mistakes of any democratic government at any time' (Stiglitz 2010a: 110). But is Joseph Stiglitz correct when he describes the bank bailouts as a 'mistake' - notably, a mistake that could be rectified if only the Obama administration would eventually realise that the foundations 
of orthodox economics are erroneous? Or does the state support for private banks that breaks all rules of neo-liberal economic theory not simply demonstrate that John Maynard Keynes and his followers are wrong to believe "that the power of vested interest is vastly exaggerated compared with the gradual encroachment of ideas." (Keynes [1936] 2008).

Considering the rapid disposal of Keynesian paradigms only a year after the financial meltdown (Sachs 2010), it seems nevertheless accurate to emphasise the dominant role of interest politics and subsidiary role of ideas in socio-economic policy making (Crouch 2010). Arguably, Keynesianism, that is a theory that encompassed the sectional interests of both capital and labour, 'could only have become the basis of policy under the conditions of social balance' (Skidelsky 2010). This leads to the key question of the next sections: what are the possibilities for counter-movements against global financial capitalism after the meltdown? Will society be able to resist this new wave of marketisation, as we could assume following Polanyi's study of past waves of marketisation and the counter-movements it triggered? Or should we share instead the 'uncompromising pessimism' (Burawoy 2010: 311) that seem to have affected many labour and industrial relations scholars (Baccaro et al. 2010)?

\section{Reasons for uncompromising pessimism}

Since the collapse of Lehman Brothers in September 2008, numerous scholars have attempted to explain the origins of the current global economic and financial crisis. Whereas bibliographic searches in the world's journal databases at the time of writing produced amazingly scarce results, reflecting the long lead time of publishing in 
assumingly 'high-impact' journals (Erne 2007), the list of books that deal with the issue is impressive. Books about the crisis lead bestseller listings in many countries that were hit by the financial meltdown. There is a broad consensus that the neo-liberal deregulation policies of the last three decades led to the current situation. Accordingly, the reintroduction of tighter regulations for the financial sector is part of almost every post-crisis reform programme. However, not only Marxists (Burawoy 2010, Harvey 2010, Foster and Magdoff 2009), but also scholars that stand in the tradition of gradual social reform doubt that regulatory reforms - that is 'the most practical set of remedies on offer' Gamble (2009: 155) - will allow a return to social democracy and full employment (Crouch 2009a).

Colin Crouch (2009a) highlighted that the growth of the US and UK economies during the past neo-liberal area did not rely on a triumph of the free market, but rather on the dubious success of an unacknowledged policy regime which he called 'privatised Keynesianism'. It is generally acknowledged that the neo-liberal labour market reforms and the efforts of business to escape national regulations secured higher profit shares for capitalists. Accordingly, the shift to economic globalisation and neo-liberalism has frequently been analysed as a business response to the declining rate of profit that Marx predicted (Skidelsky 2010, Glyn 2006). But it is not so often acknowledged that neoliberal wage moderation pressures would have prevented growth and continued capital accumulation, if unsecured consumer credit had not sustained the necessary aggregate consumer demand. Accordingly, the term privatised Keynesianism refers to the fact that economic growth in the US, the UK, and other neo-liberal economies has been sustained by private deficit spending, which in turn depended on house price inflation 
and stock exchange bubbles.

In the export-led East Asian and European economies, notably in Germany and China, consumer borrowing remained at a lower rate. Yet, these economies also benefited from the privatised deficit-spending within the neo-liberal economies. It would not have been possible for so-called ‘coordinated market economies’ (Hancké 2010) to pursue exportled growth policies, if global aggregate consumer demand had not been supported by the asset price bubbles that occurred in liberal market economies. Likewise, the profits generated by the trade surpluses of core Eurozone countries, along with the surpluses of other world regions notably in East Asia, further fuelled these asset prise bubbles in so far as they were actually financing the privatised Keynesianism in the US, UK and the peripheral Eurozone countries.

This shows how problematic varieties of capitalism typologies are, when they overstate the centrality of national institutions and disregard the interdependences of the capitalist world system, as acknowledged by institutionalist scholars who had emphasised the importance of different state traditions in the past (Crouch 2009b: 92, Meardi in this volume). Surely, national economies play different roles in the global economy. Yet, it is more accurate to distinguish them based on their location in the core or the periphery of an integrated capitalist world system, as shown, for instance, by Stefanie Hürtgen's analysis of European labour politics across transnational supply chains (2008). This conclusion is also supported by Becker and Jäger's (2009) study of the surprisingly diverging responses to the crisis in Western and Eastern Europe. Whereas UK policymakers facilitated a devaluation of the Pound, the Central and East European central 
banks resisted currency devaluations; arguably, to support the Western banks that have taken control over the local banking systems, even if this 'Eurozation' policy is hurting domestic industry in the East (Becker and Jäger 2009).

The interdependence of coordinated and liberal market economies not only questions varieties of capitalism typologies, it also entails important political implications for any counter-movement against finance capitalism. If capitalism is a world system, isn't it reasonable to suggest that national responses to its crisis will not be sufficient? It has been argued that any counter-movement to global capitalism 'must begin at the global level for it is only at that level that it is possible to contest the destruction of nature, let alone tackle the global machinations of financial capital' (Burawoy 2010: 311). Even if some sort of a global counter movement to contain capitalism's rapacious tendencies may be necessary for human survival, Michael Burawoy fears that would not be very likely to happen:

Optimism today has to be countered by an uncompromising pessimism, not an alarmism but a careful and detailed analysis of the way capitalism combines the commodification of nature, money and labor, and thereby destroys the very ground upon which a 'counter-movement' could be built (ibid: 312 ). However, even if the challenges that we are facing are indeed global, this does not necessarily validate the claim that a counter-movement to global capitalism has to begin at the global level. The just-in-time logistics of global corporations is heavily dependent on a smooth management of its transnational production chains. Within a postfordist production network, even a local strike can make a huge impact (Moody 1997). This was shown by the strike of only 1.900 workers at the Honda Auto Parts Manufacturing 
Co in Foshan in June 2010 that brought Honda's operations across China to a standstill. Moreover, after the striking Honda workers' obtained substantial wage increases, the protest movement spilled over and triggered not only an amazing strike wave in favour of higher pay and better working conditions, but also demands for a democratic labour movement in the Peoples' Republic (Dongfang 2010). Nevertheless, Burawoy correctly highlights that even if excessive marketisation triggered courter-movements in the past, this does not guarantee the rise of a successful and progressive counter-movement in the future. Whereas the Chinese rulers seem to have learnt the Polanyian lesson that market society requires state regulation, it is noteworthy that this does not preclude authoritarian solutions; incidentally, the great crash of 1929 lead not only to the New Deal and social democratic mid-century-class compromises, but also to the rise of fascism and a consolidation of Stalin's Soviet Union.

\section{Towards Post-Democracy?}

While there are little signs for a relapse into direct autocratic authoritarianism, the failures of the market society may also favour antidemocratic impulses. Whereas Polanyi's insisted that democratic market regulation and control can 'achieve freedom not only for the few, but for all' ([1944] 2001: 265), societies may also be protected from disruptive market forces by sacrificing democracy. Colin Crouch argued already in his first book, The Student Revolt, published in 1970, that there is no inherent link between democracy and capitalism.

Political systems do not exist in a vacuum. They exist in the context of, and are sustained by, social institutions, and it is not possible for a society to maintain just any structure of politics or to ensure to its citizens a system of rights and freedoms 
simply by wishing it were so (...). It is therefore entirely possible that the structure of economic powers in our society and the increasing interdependence of our political, economic, educational and social institutions should lead us to a position where our rhetoric of pluralist democracy shall cease to bear any but the most tangential relation to reality (Crouch 1970: 240).

It follows that the future of democracy depends not only on democratic beliefs but crucially also on a balance of power between the countervailing social interests, notably between the organisations of capital and labour. Only in this case can the outcome of the policy-making process reflect the best arguments, rather than mere power relations between social classes.

While democracy was instrumental in removing feudal obstacles to social change in the $19^{\text {th }}$ century, today the active use of civic, political and social citizenship rights is often perceived to be a problem. Capitalists accepted the social democratic mid $20^{\text {th }}$ century class compromise as long as it was 'the best deal that liberal capitalism could expect in a world veering towards the political extremes' (Skideslsky 2010: 326). Yet, capitalists were never really enthusiastic about sharing power with countervailing interests. It is therefore not surprising that business associations actively supported the trend towards neo-liberal politics in the late 1970s, associated with Margaret Thatcher in the United Kingdom and Ronald Reagan in the USA (Harvey 2005). After the deregulation of financial markets brought the world economy at the brink of collapse, there is a growing consensus - even within the business class - that markets ought to be re-regulated. Reregulation, however, does not require democracy, as emphasised by the technocratic regulatory capitalism of the European Union or the authoritarian 'capitalism with Asian 
values' of Singapore's long-time leader Lew Quan Yew that Deng Xiaoping praised as the model China should follow (Žižek 2009: 131).

By contrast, trade unions have been playing a very important role in the promotion of democratic rights in both the political arena and the workplace in the past (Harcourt and Wood 2004). More recently, Stevis and Boswell (2007) saw unions contributing to the democratizing of global governance. But even before the global crisis, several analysts detected a diminishing, hollowing, or even partial displacement of democracy in the Western world (Skocpol 2003, Mair 2006, Crouch 2004). Arguably, the rise of technocratic governance and the declining of autonomy of the democratic nation state in a globalising economy hamper the prospects of egalitarian democracy. Are there any prospects in unions and their political allies pushing for an alternative to the continued dominance of global financial capitalism and the demise of social and political citizenship that is associated with it? Is it possible to reconcile democracy and interest politics, if politics - despite the global financial meltdown - still seems to be dominated by a self-confident global shareholding and business executive class?

In the wake of the current economic and financial crisis, Crouch gave a very pessimistic answer to these questions: whereas democratic politics would continue to play a role in some areas, the democratic state would be vacating its 'former heartland of basic economic strategy.' Instead, economic policy would be shaped by 'the great corporations, particularly those in the financial sector' (2009a: 398), due to the decline of the manual working class and the failure of new social movements to constitute a new class that can claim to stands for the general interest of society. Even if the 
contemporary orthodoxy that social class no longer exists can be contested with sociological analysis, the increasing difficulty of subordinate groups to unite as a class entails major consequences for interest politics and democracy alike (Crouch 2004: 53). Consequently, economic policy would become a private matter of technocratic agencies and multinational corporations, even if corporations might, at times, be held accountable by public appeals to corporate social responsibility (Crouch 2009a).

\section{Reasons for cautious optimism?}

Without doubt, the current crisis is putting unions under huge pressure. Nevertheless, it is also possible that the global shareholding and business executive class emerges weakened from it. The banks' successful raids of public coffers across the world certainly demonstrated the 'strategic role' that global finance occupies in the world economy (Crouch 2010: 356). But crude demonstrations of power can also undermine the legitimacy of rulers. Successful regimes do not depend on coercion but much more crucially on their capacity to integrate subordinate groups (Cox 1983, van Apeldoorn, et al. 2009). Even if economic policies are not determined by ideas, claims that an action is consistent with the public interest are nevertheless influential in political debates. Socioeconomic interest groups rely on a convincing intellectual defence of their preferences.

Given the declining ideological strength of neo-liberal theory after the financial crisis, a shift from laissez-faire to a regulation and corporation-based defence of business interests is to be expected (Crouch 2009a). It should, however, also be noted that this implies a symbolic rather than practical shift. The pursuit of the neo-liberal agenda always required a strong state; for instance, a state that is capable of restricting trade union action (Block 2007). In liberal market economies with weak and fragmented 
government structures, such as in Canada (Thompson and Taras 2004), neo-liberalism was nearly as successful by comparison to the US and the UK, where free-marketers could count on the support of strong governments (Harvey 2005). It follows that the recent shift from free market rhetoric to the rhetoric of "regulatory" capitalism does not necessarily mean a substantial shift in capitalist preferences. Politically, however, the shift from laissez-faire to "regulatory governance" does matter, given the important role democratic norms play in the integration of subordinate groups and social classes and the legitimisation of the current liberal democratic political order.

To be sure, "regulation" does not necessarily imply undemocratic or technocratic governance. In fact, the term is often used "broadly to cover any publicly imposed rules governing a firm or industry" (McLean and McMillan 2009). According to Majone (1994), however, "regulatory governance" is defined as a particular process that is meant to relieve the political process of the assumingly negative consequences of democratic electoral pressures on the quality of regulation. Supporters of regulatory policy making have even argued that the Chilean experience could serve as an example for the European Union. After all, Pinochet effectively excluded clientelistic influences on economic policies (Drago 1998). In other words, advocates of regulatory governance aim to reduce popular influences by the exclusion of elected politicians from the policymaking process. Policy-making would be better if it was left to independent agencies: for example, to independent central banks in relation to monetary policy, or independent competition authorities in relation to competition policy. It goes without saying that the exclusion of democratic interest intermediation from the policy-making process of regulatory agencies is at variance with both pluralist and neo-corporatist theories of 
democracy and interest politics. To some extent, the theory of regulatory governance comes closest to the unitarist republican paradigm, without its democratic rhetoric however (Erne 2011). But like republican democratic theory, regulatory governance faces a major problem: how can one be sure that regulatory agencies do not serve the interest that was able to capture a dominant position in the decision-making process?

Regulatory agencies tend to be shaped by powerful political actors and ideologies, as shown, for instance, by the exclusion of social interests from the frames of references that govern the monetary policy of the European Central Bank or the competition policy of the European Commission. Regulatory governance structure 'often masks ideological choices which are not debated and subject to public scrutiny beyond the immediate interests related to the regulatory management area' (Weiler et al. 1995: 33). In this vein, regulatory governance might be more properly understood if it is conceptualised as a form of private interest government (Erne 2011). If compared to the relative ease by which exploitation in the labour market can be obscured (Burawoy 1979), however, it is nevertheless more difficult to mystify the underlying business interests of regulatory governance.

For this very reason, the increasing visibility and role of corporations and regulatory agencies in economic policy-making, which Crouch (2009a) predicted in the wake of the global crisis, might actually facilitate protective counter-movements. In fact, it is easier to politicise decisions of corporations or regulatory agencies than to politicise abstract market forces, precisely because regulatory governance is based on concrete decisions made by tangible elites. By contrast, in the market place the mutual 'relations 
of the producers, within which the social character of their labour affirms itself, take the form of a social relation between the products' (Marx [1887] 1999, ch. 1.4).

Accordingly, the making of the Single European market as such did not trigger transnational unionisms, whereas the restructuring plans of multinational corporations and the recent attracts on national labour regulation by the European Commission and the European Court of Justice politicized the race to the bottom in wages and working conditions and triggered several cases of European collective action by labour. My own analysis of emerging transnational trade union networks across Europe (Erne 2008) showed that organised labour can re-politicize technocratic policy-making, even in policy areas that are insulated from partisan politics, such as EU competition policy. Even ostensibly technocratic institutions are permeable to cross-border activist pressures. This led me to the argument that the gradual replacement of democracy by technocratic modes of governance is not irreversible. Hence, a realistic prospect exists for remedying the European Union's democratic deficit, that is, its domination by corporate interests and lack of a cohesive European people. More studies have corroborated this argument since (Gajewska 2009, Meardi 2011). Whereas the making the European single market and the monetary union did not yet lead to an effective coordination of union's wage policies, the increasingly supranational decision making processes in multinational firms and international organisations and the free movement of workers and services in the enlarged EU became in several cases significant crystallisation points for transnational union resistance.

\section{Conclusion}


The question was raised whether the various cases of transnational union resistance would give sufficient ground for cautious optimism (Phelan et al. 2009; Mitchell 2009, Martin 2009). Would a counter-movement against the ongoing wave of marketization of society not require a universal uprising of the masses (Burawoy 2010)? Not necessarily. First, it would be wrong to perceive radical and pragmatic action repertoires as mutually exclusive (Pereira 2009, Mouriaux 2010). Transformative counter-movements will only be able to mobilise people if they are able to propel concrete improvements as well as a 'reasoned utopia' (Bourdieu 1998) that can serve as an alternative to the economic fatalism of the market society. But what could the essence of such an alternative vision of economy-society relations be? Put in simple Polanyian terms, counter-movements should insist that the economic system ceases to lay down the law to society. The primacy of society over that system ought to be restored. For Polanyi, labour, land and money are fictitious commodities, because they were not originally produced for the market. Accordingly, he argued that the disestablishment of the commodity fiction, i.e. the democratic control of labour, land, and money markets, would not be an unrealistic fantasy but lie 'in all directions of the social compass' ([1944] 2001, 258f).

Second, counter-movements can also exploit the contradictions between market society and political democracy. Neither the EU nor its member states are autocratic dictatorships. Therefore, the contradiction between the declared democratic norms and the technocratic practise of socio-economic governance provide social actors with opportunities to politicize the economy not only at the level of constitutional politics, but also at lower levels of everyday policy-making. The advocates of regulatory governance perceive policy-making as an apolitical process in quest of 'best practice' 
and take objective criteria for decision-making quality for granted. But if citizens have divergent interests, not least as a result of their position in the production process, this assumption turns out to be very problematic; what is a good regulation for one citizen might be a bad one for another. For this reason, the democratization of economic policy at both the national and the supranational level requires above all collective action which politicizes everyday policy-making. There is a need for the conflict resolution mechanism offered by democratic procedures only if social actors articulate conflicting interests. As long as policy-making can be seen as a technical process, due to the absence of social and political contestation, there is no need for democratic procedures. So far, in today's Europe, trade unions are struggling to cope with the drastic results of the global financial, economic, and political crisis for their members. They have differed in their approaches, some militant ones organising general strikes, others complying more or less reluctantly with unprecedented attacks on their members' wages and working conditions. These are early days, but one thing is clear. The time now seems set for one of increasing conflict. Although some European unions accepted the post-crisis austerity measures proposed by governments more or less reluctantly, the integration of subordinate classes into the dominant socio-economic regime by social packs between the peak associations of capital and labour and the government seems to be increasingly difficult (Rehfeldt 2009, van Apeldoorn et al. 2009). While workers have accepted the logic of national 'competitive corporatism' - that is a smaller slice of the national income when the GDP was growing (Erne 2008), it is arguably much more difficult to convince workers to accept a smaller slice of a shrinking cake. Given the fading prospects for growth, it is likely that there will be an intensification of the distributional conflict between wages and profits in the years to come. This might, once 
again, lead to an unexpected 'resurgence of class conflict' (Crouch and Pizzorno 1978) that could reignite the engines of political conflict and ideological division that gave Europe its social and democratic impetus in the past (Anderson 2009).

\section{Bibliography}

Anderson, P. (2009), The New Old World, London: Verso.

Baccaro, L., R. Boyer, C. Crouch, M. Regini, P. Marginson, R. Hyman and R.

Gumbrell-McCormick, and R. Milkman (2009), 'Discussion Forum I: Labour and the global financial crisis', Socio-Economic Review, 8, 341-76.

Becker, J. and J. Jäger (2009), 'Die EU und die große Krise', Prokla. Zeitschrift für Kritische Sozialwissenschaft, 39 (4), 541-58.

Block, F. (2001), 'Introduction“ in K. Polanyi, The Great Transformation, Boston: Beacon Press, i-xxxviii.

Block, F. (2007), 'Understanding the diverging trajectories of the United States and Western Europe: A Neo-Polanyian Analysis', Politics and Society, 35 (1), 3-33.

Bode, T. and K. Pink (2010), 'Die Finanzkrise als Demokratiekrise', Blätter für deutsche und internationale Politik, 55 (6), 45-55.

Boos, S. (2008), 'Notrecht: Geld im Ausnahmezustand', Die Wochenzeitung, 23 October.

Bourdieu, P. (1998), ‘A Reasoned utopia and economic fatalism', New Left Review, 227.

Bundesrat (2008), 'Verordnung über die Rekapitalisierung der UBS AG vom 15. Oktober, SR 611.055 ', available at: http://www.admin.ch/ch/d/as/2008/4741.pdf.

Burawoy, M. (1979), Manufacturing Consent, Chicago: University of Chicago Press.

Burawoy, M. (2010), 'From Polanyi to Pollyanna: The false optimism of global labor studies', Global Labour Journal, 1 (2), 301-13.

Butselaar, E. (2008), 'Banking crisis: Expert views: After a week of turmoil, has the world changed?' The Guardian, 20 September.

Cox, R. W. (1983), 'Gramsci, hegemony and international relations: An essay in 
method', Millennium - Journal of International Studies, 12, 162-75.

Crouch, C. (1970), The Student Revolt, London: Bodley Head.

Crouch, C. (2004), Post-Democracy, Cambridge: Polity.

Crouch, C. (2009a), 'Privatised Keynesianism: An unacknowledged policy regime', British Journal of Politics \& International Relations, 11 (3), 382-99.

Crouch, C. (2009b), 'Typologies of capitalism', in B. Hancké (ed) Debating Varieties of Capitalism, Oxford: Oxford University Press, 75-94.

Crouch, C. (2010), 'The financial crisis a new chance for labour movements? Not yet', Socio-Economic Review, 8, 353-56.

Crouch, C. and Pizzorno A. (eds) (1978), The Resurgence of Class Conflict in Western Europe since 1968. Vol. 2, Comparative Analysis, New York: Holmes and Meier Publishers.

Dongfang, H. (2010), 'China’s workers are stirring', International Herald Tribune, 17 June.

Drago, M. E. (1998), The Institutional Base of Chile's Economic "Miracle": Institutions, Government Discretionary Authority, and Economic Performance under Two Policy Regimes, Florence: PhD thesis: European University Institute.

Erne, R. (2007), 'On the use and abuse of bibliometric performance indicators: a critique of Hix's 'global ranking of political science departments', European Political Science, 6 (3): 306-14.

Erne, R. (2008), European Unions. Labour's Quest for a Transnational Democracy, Ithaca, NY: Cornell University Press.

Erne, R. (2011), 'Interest Associations', in D. Caramani (ed) Comparative Politics, $2^{\text {nd }}$ edition, Oxford: Oxford University Press, 259-74.

Foster, J.B. and F. Magdoff (2009), The Great Financial Crisis: Causes and Consequences, New York: Monthly Review Press.

Gajewska, K. (2009), Transnational Labour Solidarity. Mechanisms of Commitment to Cooperation within the European Trade Union Movement, Abingdon, Oxon: Routledge. 
Gamble, A. (2009), The Spectre at the Feast: Capitalist Crisis and the Politics of Recession, Basingstoke: Palgrave Macmillan.

Glyn, A. (2006), Capitalism Unleashed, Oxford: Oxford University Press.

Hancké, B. (eds.) (2010), Debating Varieties of Capitalism, Oxford: Oxford University Press.

Harcourt, M and G. E. Wood (ed.) (2004), Trade Unions and Democracy: Strategies and Perspectives, Manchester University Press, 2004.

Harvey, D. (2005), A Brief History of Neoliberalism, Oxford: Oxford University Press.

Harvey, D. (2010), The Enigma of Capital and the Crisis of Capitalism, London: Profile Books.

Hürtgen, S. (2008), Trasnationales Co-Management. Betriebliche Politik in der globalen Konkurenz, Münster: Westfälisches Dampfboot.

Keynes, J. M. ([1936] 2008]) The General Theory of Employment, Interest and Money. Thousand Oaks, CA: BN Publishing.

Klein, N. (2008), 'Banking crisis: Expert views: After a week of turmoil, has the world changed?', The Guardian, 20 September.

Krugman, P. (2010), 'The pain caucus', The New York Times, May 31.

Mair, P. (2006), 'Ruling the void: The hollowing of western democracy', New Left Review, 42, 25-51.

Majone, G. (1994), 'The Rise of the Regulatory State in Europe', West European Politics, 17 (3): 77-101.

Martin, S. B. (2009), 'Review of 'European Unions', Perspectives on Politics, 7 (4) 1003-4.

Marx, K. ([1887] 1999), Capital, Volume One, available at: http://www.marxists.org/archive/marx/works/1867-c1/index.htm

McLean, I. and A. McMillan (ed.) (2009) "Regulation" The Concise Oxford Dictionary of Politics. Oxford University Press. Available at: http://www.oxfordreference.com/views/ENTRY.html?subview=Main\&entry=t86.e1 
146 (23 May 2011).

Meardi, G. (2011), 'Union immobility? Trade unions and the freedoms of movement in the enlarged EU', British Journal of Industrial Relations, forthcoming.

Mitchell, K.E. (2009), 'Review of 'European Unions', Industrial \& Labor Relations Review, 62 (3): 437-9.

Moody, K. (1997), Workers in a Lean World: Unions in the International Economy, New York: Verso.

Mouriaux, R. (2010), 'Le mouvement syndicale et la crise', Contretemps, 5, 63-75.

Offe, C. and H. Wiesenthal (1985), 'Two logics of collective action: Theoretical notes on social class and organizational form', in C. Offe, Disorganized Capitalism, Cambridge: Polity, 175-220.

Pereira, I. (2009), Peut-on être radical et pragmatique?, Paris: Éditions textuel.

Phelan, C., A. Martin, B. Hancké, L. Baccaro, and R. Erne (2009), 'Labour History symposium: Roland Erne, European unions', Labor History, 50 (2), 187-216.

Polanyi, K. ([1944] 2001), The Great Transformation, Boston: Beacon Press.

Rehfeldt, U. (2009), 'La concertation au sommet toujours d'actualité face à la crise? Théorie du néocorporatime et analyse comparée des relations professionnelles en Europe', Chronique International de l'IRES, 121, 40-49.

Sachs, J. (2010), 'It is time to plan for the world after Keynes', The Financial Times, 8 June.

Schmitt, C. ([1922] 1985), Political Theology. Four Chapters on the Concept of Sovereignty, Cambridge, Mass.: MIT Press.

Skidelsky, R. (2010), 'The crisis of capitalism: Keynes versus Marx', Indian Journal of Industrial Relations, 45 (3), 321-335.

Skocpol, T. (2003), Diminished Democracy: From Membership to Management in American Civic Life, Norman: University of Oklahoma Press.

Stevis, D. and T. Boswell 2007, Globalization and Labor: Democratizing Global Governance, Lanham, MD: Rowman and Littlefield. 
Stiglitz, J. (2008), 'Banking crisis: Expert views: After a week of turmoil, has the world changed?', The Guardian, 20 September.

Stiglitz, J. (2010a), Freefall: Free markets and the sinking of the global economy, London: Allen Lane.

Stiglitz, J. (2010b), 'The non-existent hand: Book review of 'Keynes: The Return of the Master' by Robert Skidelsky', London Review of Books, 32 (8), 17-8.

Thompson, M. and D. G. Taras (2004), 'Employment relations in Canada', in G. Bamber, R.D. Lansbury and N. Wailes (eds), International and Comparative Employment Relations, London: Sage, 91-118.

Van Apeldoorn, B, J. Drahokoupil and L. Horn (eds) (2009), Contradictions and Limits of Neoliberal European Governance: From Lisbon to Lisbon, Basingstoke: Palgrave Macmillan.

Weiler, J. H. H., U. Haltern, and F. C. Mayer. (1995), 'European democracy and its critique', West European Politics, 18 (4): 4-39.

Žižek, S. (2009), First as Tragedy, then as Farce, London: Verso. 